\title{
Disabling bony ankylosis of hip, knee and axial spine in a neglected patient of ankylosing spondylitis
}

\author{
Ankur Nandan Varshney, Nilesh Kumar, Ravi Anand, Nand Kumar Singh
}

Department of General Medicine, Institute of Medical Sciences, Varanasi, Uttar Pradesh, India

\section{Correspondence to} Dr Ankur Nandan Varshney, drankurnvarshney@gmail.com
To cite: Varshney $\mathrm{AN}$ Kumar N, Anand R, et al. BMJ Case Rep Published online: [please include Day Month Year] doi:10.1136/ bcr-2013-009890

\section{DESCRIPTION}

A 38-year-old man presented with inflammatory low-back pain starting at the age of 18 years. It was associated with morning stiffness that eases with works and worsens in the night, along with difficulty in changing posture in bed. After 12 years of onset of disease, the entire spine started becoming increasingly stiff with gradual loss of lumbar lordosis and development of thoracic kyphosis. At the same time he also reported pain and swelling in bilateral knee joint, limiting his day-to-day activity and later developed stiffness of joint and disability. For the 4 years he has been completely bedridden and unable to perform his routine activities without help. On examination, we found fixed flexion deformity of knee joint and severe kyphosis of spine with the patient unable to stand on his own.
On primary investigations, erythrocyte sedimentation rate $=73(>10), C$ reactive protein $=174.4$ $(>5)$, human leucocyte antigen B27 positive, X-ray reveals fusion of bilateral sacroiliac joint along with ankylosis of spine (figure 1) and knee (figure 2).

Ankylosing spondylitis (AS) usually starts in second to third decade of life and progresses over decades ${ }^{1}$ to produce varying kyphosis, restricted neck movements with radiological evidences of sacroilitis in early stage and complete fusion of joint in later stages with or without spinal fusion.

Nearly 30\% of patients with AS develop peripheral arthritis. This is usually rare and is asymmetric with oligoarthitis affecting larger joints particularly hip and knee. ${ }^{2}$

With modern antirheumatic tumour necrosis factor-blockers and non-steroidal anti-inflammatory

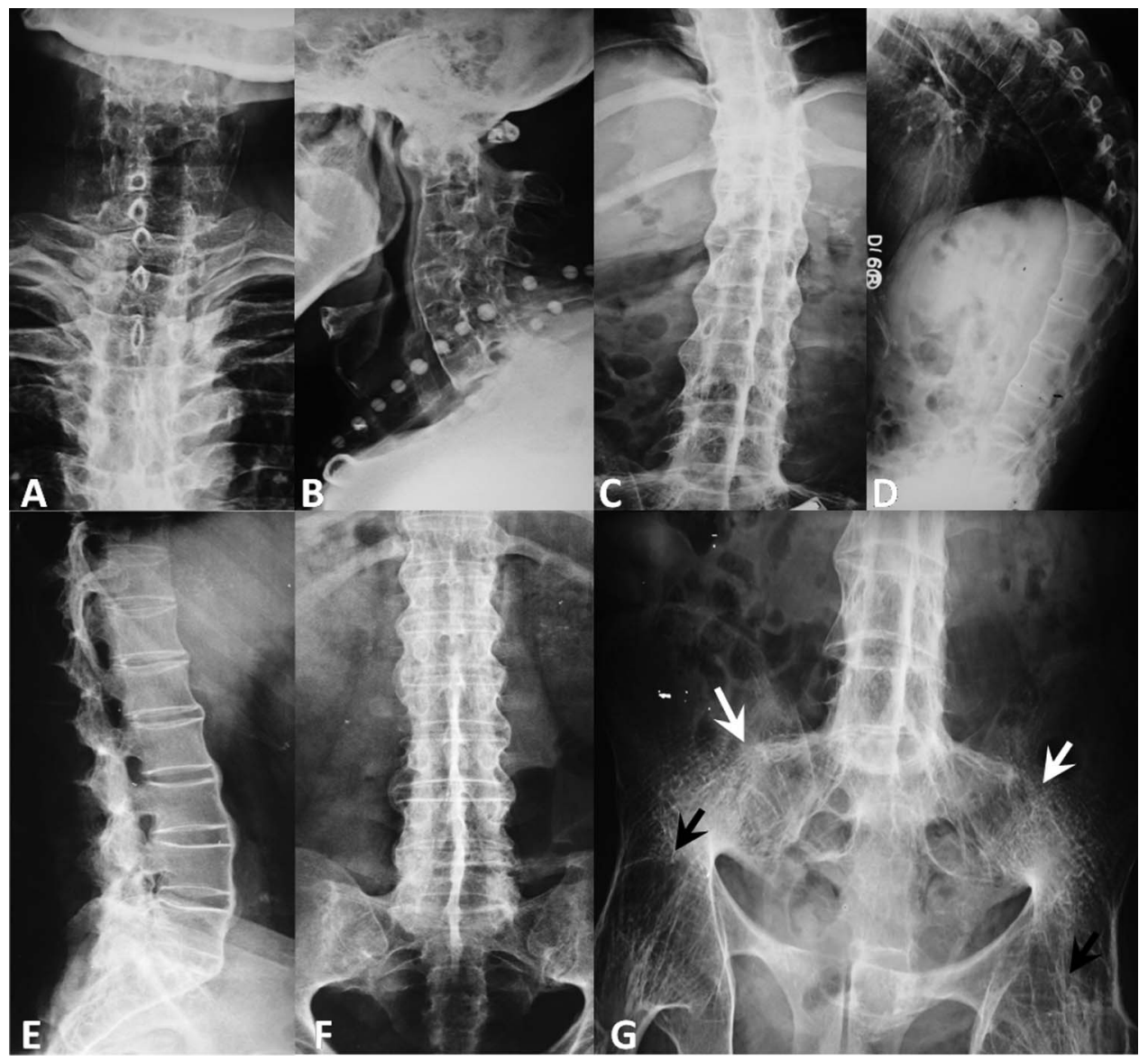

Figure 1 Plain radiographs anteroposterior and lateral views of cervical ( $A$ and $B)$, dorsal (C and D) and lumbar ( $E$ and $F$ ) spine showing calcification of anterior and posterior longitudinal ligaments with ossification in interspinous, paraspinous and ligamentum flavum. Plain radiograph of sacroiliac joint shows bony ankylosis at bilateral joints (white arrows), incidental bony ankylosis at bilateral hip joints (black arrows) is also seen (G). 


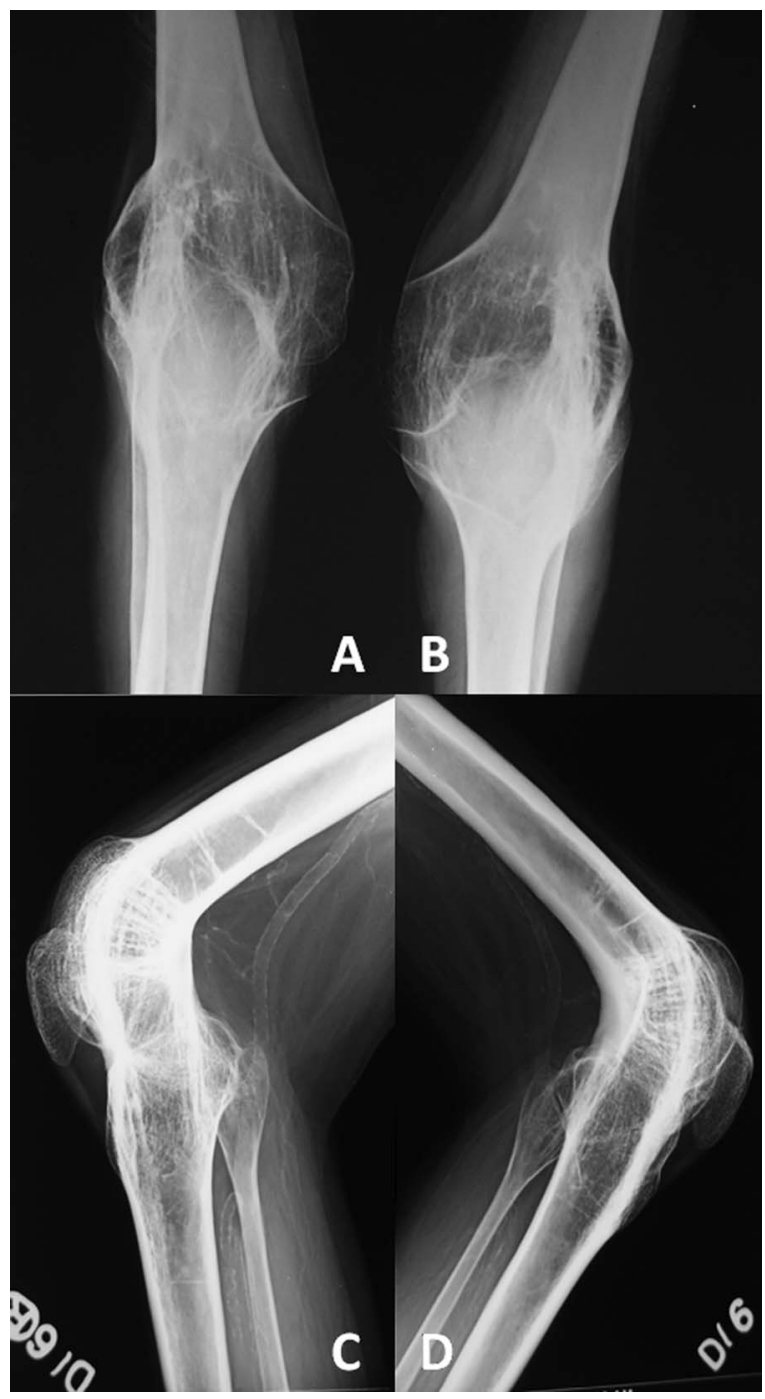

drugs such severe deformity is rarely seen and reflects delay in diagnosis and seeking medical care. ${ }^{3}$

\section{Learning points}

- Ankylosing spondylitis is one of the commonest diseases presented with low back inflammatory pain in the rheumatology clinic.

- The disease can be easily diagnosed with its clinical, serological and radiological features.

- Early use of biologicals can prevent progression of disease and occurrence of deformities.

Contributors All authors were equally responsible for the diagnosis and management of the patient. All contributed equally in preparation of figures and review of the literature. ANV wrote the paper.

Competing interests None.

Patient consent Obtained.

Provenance and peer review Not commissioned; externally peer reviewed.

\section{REFERENCES}

1 Keat A. Ankylosing spondylitis. Medicine 2010;38:185-9.

2 Hamdi W, Alaya Z, Ghannouchi MM, et al. Associated risk factors with worse functional prognosis and hip replacement surgery in ankylosing spondylitis. Joint Bone Spine 2012;79:94-102.

3 Schett G, Rudwaleit M. Can we stop progression of ankylosing spondylitis? Best Pract Res Clin Rheumatol 2010:24:363-71.

Figure 2 Plain radiographs of both knee joints anteroposterior $(A$ and $B$ ) and lateral views (C and D) showing bony ankylosis at bilateral joints. Associated fixed flexion deformity and vascular calcifications are also seen.

Copyright 2013 BMJ Publishing Group. All rights reserved. For permission to reuse any of this content visit http://group.bmj.com/group/rights-licensing/permissions.

BMJ Case Report Fellows may re-use this article for personal use and teaching without any further permission.

Become a Fellow of BMJ Case Reports today and you can:

- Submit as many cases as you like

- Enjoy fast sympathetic peer review and rapid publication of accepted articles

- Access all the published articles

- Re-use any of the published material for personal use and teaching without further permission

For information on Institutional Fellowships contact consortiasales@bmjgroup.com

Visit casereports.bmj.com for more articles like this and to become a Fellow 